\title{
Investigação etiológica de meningites em amostras de líquido cefalorraquidiano de pacientes atendidos no Hospital das Clínicas da Universidade Estadual de Campinas
}

\author{
Sabrina B. Jaconis*, Paula V. Bottini, Célia Regina Garlipp
}

\section{Resumo}

A meningite bacteriana é a patologia mais grave dentre os processos infecciosos do sistema nervoso central. Seus principais agentes etiológicos são Neisseria meningitidis, Streptococcus pneumoniae e Haemophilus influenzae. Já na meningite viral, o enterovírus e o adenovírus são os mais prevalentes. O exame do líquido cefalorraquidiano (LCR) é o padrão-ouro no diagnóstico dessa infecção. O emprego de técnicas imunoenzimáticas e a reação da PCR permite a identificação dos agentes etiológicos com elevadas sensibilidade, especificidade e rapidez. O objetivo desse estudo é identificar o agente etiológico das meningites por meio da análise molecular e/ou imunoenzimática em amostras de LCR de pacientes atendidos no Hospital de Clínicas da UNICAMP, no período de janeiro de 2017 a maio de 2019. No intervalo, 845 amostras foram encaminhadas para pesquisa do agente etiológico viral (Grupo 1), 27 para o agente bacteriano (Grupo 2) e 41 para os demais (Grupo 3). No grupo 1, o adenovírus foi o mais prevalente, correspondendo a $57,8 \%$ das amostras com agente viral detectado, enquanto no grupo 2, foi o S. pneumoniae, representando $20 \%$. Em $67 \%$ das amostras, o patógeno não foi detectado. Apesar de todo o avanço tecnológico, o diagnóstico etiológico das meningites continua sendo um desafio. Técnicas imunoenzimáticas e de biologia molecular têm se mostrado ferramentas importantes no estabelecimento da etiologia das meningites, tendo impacto positivo na vigilância epidemiológica dessas doenças.

\section{Palavras-chave:}

meningites investigação etiológica; líquido cefalorraquidiano análise molecular; líquido cefalorraquidiano análise imunoenzimática

\section{Introdução}

A meningite é a infecção das leptomeninges e do espaço virtual entre elas, o espaço subaracnoide. O exame do LCR é o padrão-ouro no diagnóstico dessa afecção infecciosa, mostrando alterações citológicas, bioquímicas e microbiológicas bastante características. O emprego de técnicas imunoenzimáticas e de biologia molecular como a reação da PCR (polimerase chain reaction), capaz de identificar o DNA dos patógenos, garante a identificação dos agentes com elevadas sensibilidade, especificidade e rapidez. O objetivo desse estudo é identificar o agente etiológico das meningites por meio da análise molecular e/ou imunoenzimática em amostras de LCR de pacientes atendidos no Hospital de Clínicas da UNICAMP, no período de janeiro de 2017 a maio de 2019.

\section{Resultados e Discussão}

Analisamos os resultados de todas as amostras de LCR com suspeita de meningite, independentemente de sua etiologia, encaminhadas ao Instituto Adolfo Lutz (IAL) para identificação do agente etiológico. No $I A L$, a reação da PCR era utilizada para identificação da maioria dos patógenos, sendo que alguns agentes específicos como Dengue e Chikungunya eram determinados pelo enzimaimunoensaio. No intervalo estudado, o Grupo 1 foi formado por 845 amostras enviadas para pesquisa do agente etiológico viral. Em apenas 19 amostras, identificou-se o vírus sendo que o Adenovírus foi o mais prevalente, correspondendo a $57,8 \%$ destas e em 4 amostras a identificação de arbovírus mostrou-se inconclusiva. O Grupo 2 era constituído por 27 amostras com solicitação de PCR para meningite bacteriana. Neste grupo, identificou-se o $S$. pneumoniae em 6 amostras, representando $20 \%$, e o $H$. influenzae em apenas 1 amostra, enquanto 1 amostra teve resultado positivo para herpes simples tipo 1 e as demais resultado negativo. Seis amostras estavam com resultados indisponíveis. O Grupo
3 era composto por 41 amostras que foram enviadas para pesquisa de fungos, TRM-TB, protozoários, proteína 14-33 e eosinofilia. O DNA para Mycobacterium tuberculosis foi detectado em 1 amostra, as demais tiveram resultado negativo ou indisponível. O agente etiológico não foi identificado em $67 \%$ do total analisado, porcentagem esta semelhante ao relatado no Boletim epidemiológico 03 da Secretaria de Vigilância em Saúde do Ministério da Saúde ${ }^{1}$, divulgado em janeiro de 2019. Neste boletim, a meningite bacteriana não especificada representa $65,1 \%$, demonstrando a dificuldade de identificação do agente etiológico. Nosso estudo confirmou a observação de que mesmo utilizando técnicas mais sensíveis e específicas, apenas uma pequena porcentagem das amostras liquoricas tem seu agente identificado.

\section{Conclusões}

Apesar de todo o avanço tecnológico, o diagnóstico etiológico das meningites continua sendo um desafio. Técnicas imunoenzimáticas e de biologia molecular têm se mostrado ferramentas importantes no estabelecimento da etiologia das meningites o que tem um impacto positivo na vigilância epidemiológico destas doenças, permitindo que medidas de saúde importantes sejam adotadas, visando proteger a população, bloquear a cadeia de transmissão e iniciar mais precocemente o tratamento específico evitando, assim, sequelas e óbitos.

1. Secretaria de Vigilância em Saúde, Boletim Epidemiológico: Meningites bacterianas não especificadas no Brasil, 2007 a 2016 Vol. 50 No 03, 2019 Ministério da Saúde. Disponível em

http://portalarquivos2.saude.gov.br/images/pdf/2019/fevereiro/01/2018038.pdf. Último acesso em 19 de junho de 2019 